should supplement each other, and he tries to break down the still existing barriers of mistrust between morphologists and biochemists. He places the emphasis on what is now being called 'molecular biology' rather than on 'classical' biochemistry: little is said about the description of natural substances, except, of course, nucleic acids and proteins. If Prof. Kuyper's book succeeds in breaking down existing barriers between cytologists and molecular biologists, it will have served a most useful purpose. The best way, for molecular biologists, to get the confidence of the cytologists is to show them that the structure of the nucleic acids and their role in the synthesis of specific proteins can be understood without too much effort. Cytologists must realize that the concepts of molecular biology must be transferred from the ' $E$. coli \pm phage' system to real cells.

The book begins with a general introduction: the main cytochemical methods, the chemical composition of the cells (with the accent placed on nucleic acids and proteins, as already mentioned) and a brief description of the cell are successively examined. Chapter 2 deals with the production and storage of energy: ATP, enzymes, coenzymes, glycolysis, tricarboxylic acid cycle, oxidative phosphorylation, mitochondria, hexose-monophosphate shunt, photosynthesis and chloroplasts are well presented. Chapter 3 is devoted to the "organization of frontiers": the main topics are, of course, the cell membrane, its permeability, active transport, pinocytosis and related processes. In Chapter 4 the author deals with protein synthesis: the role of nucleic acids and ribosomes, the genetic control, the secretion of proteins-including the possible role of the Golgi apparatus-are discussed. Chapter 5 (the organization of mechanical activity) is devoted to the structure of muscle and the mechanism of its contraction; cilia, flagellæ and the mitotic spindle are compared with muscle cells. The next chapter deals with mitosis and meiosis, chromosomes, DNA structure and reduplication. In Chapter 7, Prof. Kuyper discusses the organization of specificity and diversity: biochemical genetics, transfer of information from the nucleus, the organization of the interphase nucleus, giant and lampbrush chromosomes, differentiation are presented in little more than 20 pages (excluding the figures). Chapter 8 deals with the organization of regulation (induction of enzymes, regulation of their activity, Pasteur effect, cellular homeostasis, hormonal regulations). The concluding remarks end with the wish that more theoretical chemists and solid-state physicists might become interested in the organization of cellular activity.

The aims of the author are obviously excellent. However, criticisms cannot be avoided: if the presentation of the book (there are many good electron micrographs) is pleasant-despite too many misprints-its reading must often be confusing for beginners, university students in particular : for example, mitochondria, Golgi, periodic acid Schiff Foulgen 'coloration', DNA, RNA, RNaso, DNase are mentioned on pages 6 and 12 ; but one must wait until p. 33 before nucleic acids are discussed and until p. 4I before the general morphology of the cell is described. Another very serious drawback-which is admitted by the author himself-is the almost complete absence of bibliography: references are limited to reviews and books, and the reader is left with a dogmatic impression.

There are very few factual errors; but the lack of quotations makes it almost impossible to check doubtful statements. For example, to which species might belong the gastrula, made of 128 cells only, in which nuclear transplantations were made (p. 242): not the amphibian gastrulæ studied by Briggs, King, Moore and Fischborg, I hope. The attitude of the author towards biological and cytological problems is often over-sceptical: he does not believe much in the virtues of histological fixation or autoradiography with tritium-labelled precursors. Although he does not admit it, Prof. Kuyper obviously retains some sympathy for a "vital force". Therefore, viruses-which are not "known" for certain to bo "living" -have been barred from the book. It is true that they are "decidedly not cellular in nature", but . . . they multiply in cells and change the organization of the latter after infection. Unfortunately for the author, the book was written and published a little too early: messenger RNA is barely mentioned, the Monod-Jacob theory of geno regulation is not discussed and the work on coding of Nirenberg and the Ochoa school was not yet known.

But Prof. Kuyper is certainly not to blame, if molecular biology is advancing at full speed, too fast for writers of scientific books. Despite a number of shortcomings, the present book is very welcome and should interest molecular biologists as well as cytologists.

J. BRACHET

\section{AIRBORNE RADAR AND WEAPONS SYSTEMS}

\section{Airborne Radar}

By Donald J. Povejsil, Robert S. Raven and Peter Waterman. (Principles of Guided Missile Design.) Pp. $x x+823$. (Princeton, N. J.: D. Van Nostrand Company) Ine.; London: D. Van Nostrand Company, Ltd., 1961., 131s. $6 d$.

HE books issued in the series Principles of Guided

Missile Design are, in many rospects, successors to tho Radiation Laboratory Series of the $1948 / 49$ period. In the early series the emphasis was on the techniques of radar and engineering design details were given, but in this present series the emphasis is on the principles of operation. This volume on Airborne Radar is an excellent book, which should be of great value to designers of airborne radar systems and to serving officers, giving them a good insight into concepts of weapon systems.

The mathematical treatment is well handled, and the physical significance is clearly brought out in many examples. The volume is most up to date, and it is probable that because only the general principles of the systems and devices are described, security clearance for publication has been given. There is a possibility that attempts have been made to cover too much ground and descriptions are given of many devices, the omission of which would not have lessened tho value of tho book.

After briefly describing the general characteristics of radar and the types of operation of which they are capable, the importance of considering radar as a major component in an overall weapon system is stressed. In the example dealing with air interception the inter-relationships of the many sub-systems are examined and the requirements of the air interception radar derived.

The range performances of various radar systems are examined, taking into account the propagation factors, including the effect of the atmosphere and the backscattering effect of the terrain and precipitation. A concise theoretical treatment is given of signal and noise analysis with many examples. The general properties of many different types of radar are given, and their advantages and disadvantages are clearly brought out.

In the following chapters the principles of operation of the radar system are discussed with the topics including: the receiver; automatic gain control; automatic fre. quency control: angle stabilization during searching and tracking; automatic angle and range tracking; the microwave properties of aerials, radomes and waveguides; power generation using magnetrons and klystrons; the basic features of display systems and their inter-rolation with the human operator; the mechanical design and packaging of airborne equipments. Many chapters are concluded with references to new techniques and devices which may have possible future application. In the final chapter, the application of radar and infra-red radiation is described for use in airborne navigation and air to ground surveillance systems. R. Aspinalu 